\title{
Maud Ballington Booth of the Volunteers of America
}

\section{SUSAN FULTON WELTY}

Maud Ballington Booth, Salvation Army leader, pioneer slum worker in New York, "Little Mother of the Prisons," co-founder and leader with her husband of the Volunteers of America, author, popular preacher and much-sought-after Chautauqua and Lyceum lecturer, was born and grew to adulthood in England. During her sixty-one years in the United States, however, from 1887 to 1948, she traveled, worked, and lectured in almost every state, including Iowa. Her Iowa connections were not numerous, but some were close. As a result, outside of the files of The Volunteers of America, national religious and charitable organization, at their New York City Headquarters, The University of Iowa Libraries hold what is almost certainly the best collection of biographical and autobiographical materials relating to her life and career.

Aside from some seventy letters in the University's Redpath Chautauqua Collection, most of these materials came as printed or typed copies of various publications by, about, or related to Mrs. Booth, when Susan Fulton Welty, formerly of Fairfield, Iowa, presented to the University Libraries her manuscript of Look Up and Hope, The Life of Maud Ballington Booth. Mrs. Welty's book had grown out of the inheritance of her mother's long-time friendship with Mrs. Booth.

In 1969, following the death of Mrs. Booth's only daughter, Theodora Booth, other biographical materials relating to Mrs. Booth were generously passed on to Mrs. Welty by Miss Booth's executor, Miss Bertha Moeri, of Great Neck, New York. These, too, are now in The University of Iowa Libraries. They include Mrs. Booth's own souvenirs from her first notable evangelistic effort, at the University of Upsala in Sweden, when she was a twenty-year-old traveling Salvationist. Among these early items is one of the original red posters, printed in Latin, 
which invited the students at Upsala to hear Maud Charlesworth's lecture in 1886.

More relevant to Mrs. Booth's American career is her bulky scrapbook of newspaper articles detailing the national uproar in 1895 and 1896 when Maud and her husband Ballington Booth were ousted by General William Booth, Ballington's father and leader of the Salvation Army, from the command of the United States branch which he had sent them to head in 1887, shortly after their marriage. More personally interesting is a handwritten tablet concerning the Ballington Booths' break with the Salvation Army. It was written some years after the event for the information of Volunteers of America officers, but never circulated or published. Intergroup and personal tensions show publicly, however, in a collection of newspaper stories of December, 1897, shortly after the Volunteers of America was formed, when Mrs. Booth was hospitalized in New York with a nearly-fatal aortic aneurysm. Frederick Booth-Tucker, her brother-in-law, who had come with his wife Emma Booth to take over the command of the American Salvation Army, declared publicly in Chicago that, far from dying of a broken heart from Salvation Army harassment as New York papers headlined, Mrs. Booth was merely shamming illness to gain sympathy. Ballington Booth left it to her "eminent physicians" to "answer the slight put upon them." They did.

Among many miscellaneous items, two autobiographical records are particularly interesting: "Memories of Childhood" and "Memories of Girlhood." The cheap stenographer's notebook in which Mrs. Booth penciled "Memories of Childhood" is undated, but was probably filled in the summer of 1931 or shortly afterward. Mrs. Welty and her husband visited the Booths that summer in their home at Blue Point, Long Island, and were taken by Mrs. Booth in her motorboat for a stay at her Fire Island cottage retreat. While the midwestern Weltys waded and jumped gingerly in the Atlantic surf, Mrs. Booth sat in a folding camp chair on the beach, soaking up sunshine and scribbling in just such a notebook. She explained, "I have been asked so many times for an autobiography, I am making a start on one." The deepening Depression had probably prodded her into action, for her personal life and the Volunteers of America work were both suffering financially, and she was then sixty-six years old. It was probably a relief to her to escape from Depression problems into the carefree atmosphere of the childhood days when she and her older sister Florence Charlesworth -later famous as Florence Barclay, author of The Rosary, The Mistress of Shenstone, and half a dozen other popular novels-encouraged each other in pranks. 
Mrs. Booth wrote on the inside cover of the notebook, "I am just writing this as I remember, for I must trust to a 'ghost writer' to put it into shape for publication. That makes it much simpler for me, and I have not to think of literary style or effect." Nor did she, as the careless spelling and punctuation show. Nevertheless, as an experienced speaker and writer she had a flair for pointing up anecdotes. It is easy to see how her avid interest in gardening and birds grew out of her idyllic memories of her first four years in the Surrey countryside. Her father's rectory stood across the one main village street of Limpsfield from his little Norman church with its ancient lych gate and shadowy graveyard, among thatched cottages and elegant homes interspersed down lanes lined with hawthorn and wild roses, and a common to play on where golden gorse bloomed honey-sweet. Maud did dislike the fox hunts, however, and she and Florrie rejoiced in triumph when they once managed to rescue a harried fox from its red-coated pursuers.

In her later childhood Maud Charlesworth tasted outdoor freedom again on many holidays, swimming and sailing by the sea, climbing mountains in Wales, traveling to France and Switzerland, and even at home in London in her mother's garden. Restricted as that was, it still had room for a pony and plays of knights and ladies. But in Saint Anne's big rectory on Commercial Road in London, there were always governesses and lessons to cope with, and beyond them, religion and Saint Anne's Church dominated family activities. Reverend Samucl Charlesworth's religion was scholarly and reserved, even though he had deliberately chosen to give up the aristocratic Limpsfield parish to work among the city poor. Maud's mother, however, was always active in social concerns. In Limehouse, and even on holidays, she encouraged any helpful Christian groups and activities which she could. It was Mrs. Charlesworth, on a seaside holiday with her daughters when Maud was fourteen, who introduced the girls to ardent young women from the Christian Mission then working to reform the rough sailors of the port. When the Christian Mission became the Salvation Army, mother and daughters retained their admiration for its workers, and it was Mrs. Charlesworth who took Maud to the Salvation Army Holiness meeting at which she first met Ballington Booth, General William Booth's second son, whom she afterward married.

Mrs. Booth's "Memories of Girlhood," originally handwritten in another notebook now lost, fortunately exists in a typed copy. It is chiefly concerned with her late teens, for in her sixteenth year her life changed drastically. Her sister Florrie, from whom she had always been almost inseparable, and on whom she had always leaned because 
Florrie was outgoing and she was shy, married and moved away. Then their much-loved mother died. As Mrs. Booth often declared afterward, "I never was a child again." She returned to her school at Belstead after the funeral, but began a struggle with her father for permission to work with the Salvation Army. She finally won it, and joined Catherine Booth's first foray into Switzerland as her aide-decamp and interpreter. Samuel Charlesworth, however, was never reconciled to his daughter's attachment to the Salvation Army after its persecution in Switzerland, and when she married Ballington Booth against his will, he disinherited her. "Memories of Girlhood," however, passes lightly over their alienation. Maud was more interested in describing her Salvation Army adventures, and in her happy romance, which endured through more than fifty years.

The Booths' ability to lose themselves in their work stood Ballington and Maud Booth in good stead many times in their later careers. "Memories of Childhood" and "Memories of Girlhood" apparently concluded Mrs. Booth's attempt at autobiography, and neither was ever published. These notebooks bring the story up to the time when the Booths' greatest work began. That work has to be documented from other sources.

Ballington and Maud Booth headed the Volunteers of America together until his death in 1940, and she alone as his successor until 1948 -more than half a century. Their only son, Charles, long a leading Volunteers officer, was then elected General, and served ably until his retirement. Under his dedicated successor, General John F. McMahon, another second-generation long-time Volunteers officer, the organization will soon celebrate its 75 th anniversary with nationwide ceremonies. Many of its activities have changed over the years, as old social problems are met in new ways, but the rehabilitative work with men in prison or on parole, for which Mrs. Booth was most famous, still continues. So do updated versions of her slum work, rehabilitative workshops and resale stores, homes for stranded women and children, summer camps for slum children, shelters for transient men, children's day-care centers, and, most recently, sponsorship of low-cost housing complexes in many American cities. Old or new, these projects are accompanied by personal, individual help to people in need, without regard to race, creed, or color, under the Volunteers of America motto, "For God and Country." The University of Iowa Libraries' material on Maud Ballington Booth's life shows clearly that her pioneer social work still exerts a strong influence today, even in a social environment very different from her own. 


\section{CIVES ACADEMICI!}

\section{Cras, Dominica}

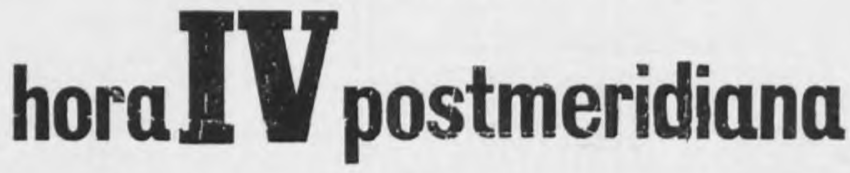

in

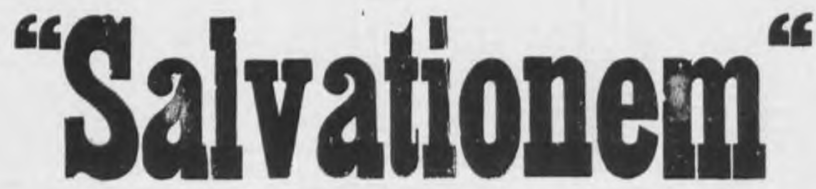

vos DIIIIes venite!

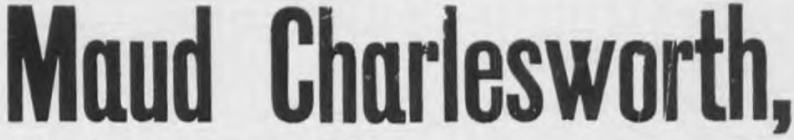

Britanna illa, quæ gloria

belli HELVETICI floret, publice loquetur.

Vemon niri aivis amulemiras in

4

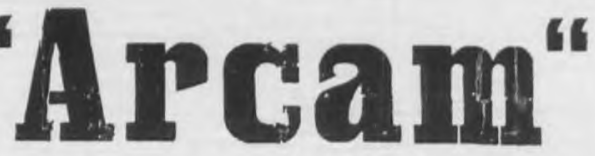

aditum habelit.

Poster, in Latin, announcing a lecture by Maud Charlesworth for the students at the University of Upsala, Sweden, on Sunday, April 18, 1886. 